\title{
Öğretmen Adaylarının İnsan Haklarına İlişkin Algıları*
}

\author{
Celalettin ÇELEBİ 1 ic
}

${ }^{1}$ Necmettin Erbakan Üniversitesi, Konya, Türkiye, celalcelebi75@gmail.com

*Bu çalışma 22-25 February 2021 tarihinde International Symposium of Scientific Research and Innovative Studies Sempozyumunda sözlü bildiri olarak sunulmuştur.

\begin{tabular}{|c|c|}
\hline Makale Bilgileri & ÖZ \\
\hline $\begin{array}{l}\text { Makale Geçmişi } \\
\text { Geliş: 03.05.2021 } \\
\text { Kabul: } 27.05 .2021 \\
\text { Yayın: } 30.06 .2021 \\
\text { Anahtar Kelimeler: } \\
\text { İnsan hakları } \\
\text { İnsan hakları ihlalleri } \\
\text { Zihin haritaları }\end{array}$ & 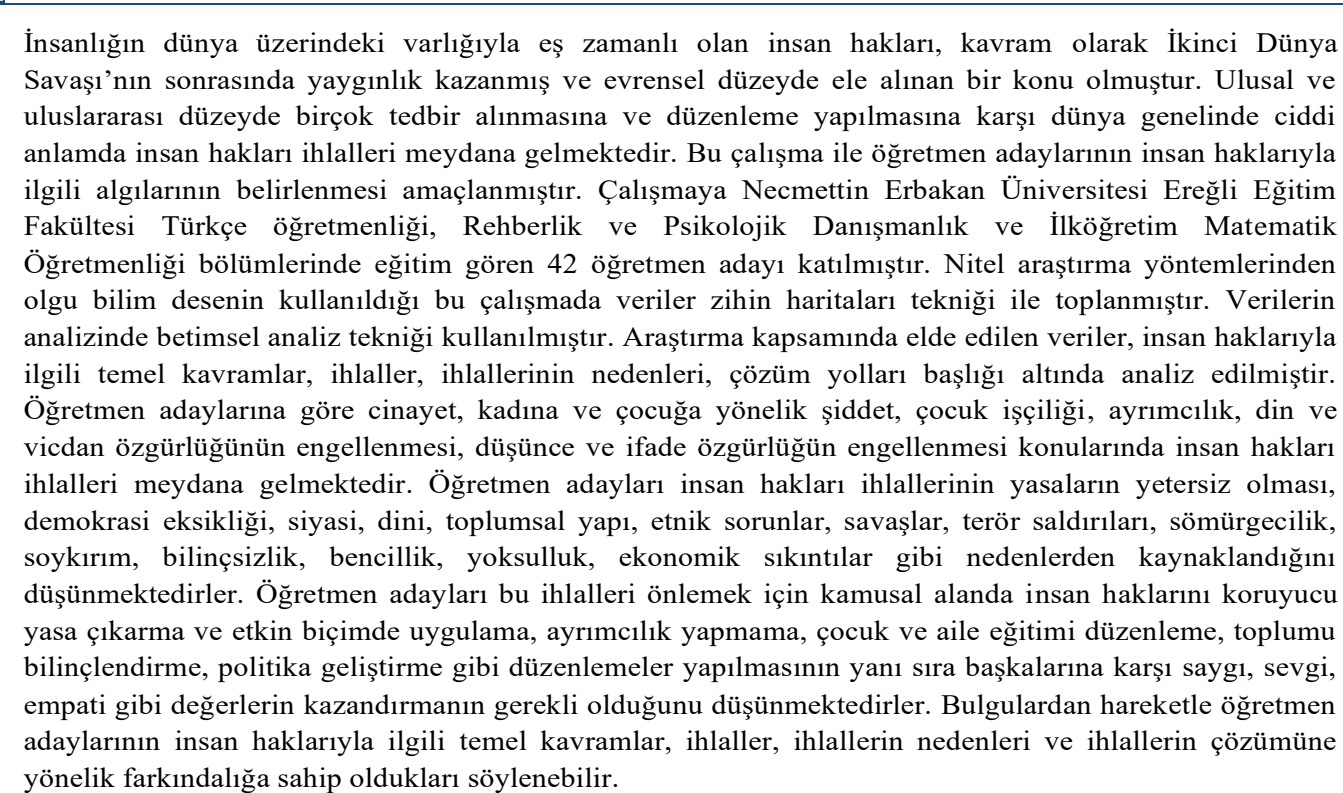 \\
\hline
\end{tabular}

\section{Perceptions of Teacher Candidates on Human Rights}

\begin{tabular}{ll}
\hline Article Info & ABSTRACT \\
\hline Article History & $\begin{array}{l}\text { Simultaneous with the existence of humanity in the world, human rights, after the Second World War, have } \\
\text { Received: 03.05.2021 } \\
\text { become a widespread concept and a universal issue. At national and international levels, serious human rights } \\
\text { Accepted: 27.05.2021 } \\
\text { violations have been taking place around the world despite many measures and regulations. With this study, it } \\
\text { hublished: 30.06.2021 } \\
\text { heywords: }\end{array}$ \\
$\begin{array}{l}\text { human rights } \\
\text { studying at Necmettin Erbakan University, Eregli Faculty of Education in departments of Turkish Language } \\
\text { Teaching, Guidance and Counseling, and Mathematics Teaching participated in this study. The } \\
\text { phenomenology design, one of the qualitative research methods has been adopted in the study, and the data } \\
\text { violations }\end{array}$ & $\begin{array}{l}\text { have been collected through mind maps technique. In the analysis of the data, describe analysis technique has } \\
\text { been used. The data obtained have been categorized under the headings of basic concepts related to human } \\
\text { Mights, violations, causes of human rights violations, and remedies for human rights violations. The teacher } \\
\text { candidates have stated that human rights violations such as murder, violence against women and children, } \\
\text { abuse, child labor, language, religion, race, gender discrimination, denial of the right to education, prevention } \\
\text { of freedom of religion and conscience, and prevention of freedom of thought and expression occur. Moreover, } \\
\text { teacher candidates think that violations of human rights occur because of inadequate laws, lack of democracy, } \\
\text { political, religious, social structure, ethnic problems, wars, terrorist attacks, colonialism, genocide, } \\
\text { unconsciousness, selfishness, poverty, and economic difficulties. In order to prevent those violations, teacher } \\
\text { candidates think that it is necessary to make regulations such as making and implementing effective laws to } \\
\text { protect human rights in the public sphere, educating children and families, being a non-discriminant person, } \\
\text { getting public awareness, developing policies, and gaining affective qualities such as respect for others, love } \\
\text { and empathy. It can be concluded that the teacher candidates have knowledge about the basic concepts of } \\
\text { human rights, violations, causes of violations and their solutions. }\end{array}$
\end{tabular}

"This article is licensed under a Creative Commons Attribution-NonCommercial 4.0 International License (CC BY-NC 4.0)" 


\section{GíRiş}

İnsanlığın "insan hakları" için yaptığı mücadelenin tarihi eski zamanlara dayanmasına rağmen insan haklarının terim olarak kullanılması literatürde yenidir. İnsanlar şu an sahip oldukları hakları elde edebilmek için zahmetli ve yoğun bir gayret göstermişlerdir. İnsan hakları bu zor süreçlerin sonucunda sosyal ve ahlaki bir değer olarak herkesin üzerinde hem fikir olduğu ortak bir anlayışa sahip değer haline gelmiştir. "İnsan hakları" terimi insan aklının üretimi sonucu 20. yüzyılın 2. çeyreğinden sonra özerk hukuksal disiplin içinde hukuki bir kavram olarak insanlığın ortak tarihi birikimini yansıtan bir ürün olmuştur (Kara, 2017). Ancak insanlığın tarihiyle eş zamanlı bir kavram olan insan hakları ihlalleriyle ilgili yerel ve evrensel düzeyde birçok tedbir, yasal düzenleme vb. önlemler alınsa da gittikçe artan sayıda ve seviyede insan hakları ihlalleri meydana gelmektedir.

Yapay zekanın hayatımıza girdiği, dünyamız dışında yaşam için hazırlıkların yapıldığı, teknolojik gelişmelerin zirveye çıktığı 21. yüzyılın ilk çeyreğinde savaşlar, iç savaşlar, soykırımlar, ekonomik yetersizlikler, devletler arası güç mücadeleleri, etnik sorunlar, kanun ve yasaların yetersizliği, eğitimsizlik, aç gözlülük, göçler vb. nedenlerden dolayı dünyamızda artan sayıda insan; cinayet, şiddet, tecavüz, yoksulluk, iş kaybı, göçe zorlanma, yetersiz beslenme, barınma vb. ihlallere maruz kalmaktadır. Ekonomik gereklilikler, ailesine katkıda bulunmak, toplumsal nedenlerden dolayı Birleşmiş Milletler'in 2020 yılı verilerine göre, dünyada 5-17 yaş aralığında, 218 milyon çocuk iş̧̧i bulunmaktadır. Sadece Türkiye'de 2020 yılında Kasım ayına kadar 260 kadın cinayeti meydana gelmiştir. Ayrıca, kadınlar gittikçe daha fazla taciz, tecavüz ve şiddet (92 tecavüz, 136 taciz, 731 şiddet vakası) ile karşılaşmaktadırlar (Kadın Cinayetlerini Durduracağız Platformu, 2020).

Birleşmiş Milletler verilerine göre 2019 yılı sonu itibarıyla dünyada, 79,5 milyon zorla yerinden edilmiş insan, 26 milyon mülteci, 45,7 milyon kendi ülkeleri içinde yerinden edilmiş kişi, 4,2 milyon sığınmacı tespit edilmiştir. Sadece ülkemizde 2020 sonunda 3,6 milyon Suriyeli ve 323,000 diğer milletlerden insanlar mülteci ve sı̆̆ınmacı olarak bulunmaktadırlar. 0-18 yaş arası çocukların ve kadınların toplam sayısı ise 2 milyon 565 bin 823 kişidir (The UN Refugees Agency, 2020a, 2021b).

İnsan hakları kavramı farklı biçimlerde tanımlanabilir. Ancak, en dikkat çeken niteliğini baz alarak tanımlamak gerekirse, insan haklarının, hiçbir ayrım gözetmeksizin bütün insanların, sırf insan olmalarından dolayı sahip oldukları haklar olduğu ifade edilebilir (Uygun, 2000). İnsan hakları dil, din, ırk ayrımı olmadan her bir bireyin şarta bağlı olmaksızın yararlanabileceği haklardır. Hukukta "kamu özgürlükleri", "kamu hürriyetleri”, "temel hak ve özgürlükler" biçiminde ifade edilen insan haklarının uluslararası belgelerde veya anayasalarda net bir tanımı yoktur. İnsan hakları insanın doğumla elde ettiği vazgeçilmez olarak görülen yaşama, ikamet etme, eziyet ve işkenceye tabi tutulmama, mülk edinme, inanç özgürlüğü gibi en temel haklar bu kavramın özünü oluşturur. İnsan hakları uygulamada iki grupta değerlendirilmektedir. Birinci grubu insanlara sadece insan olduğu için verilen haklar oluşturur ki buna "statü hakları" denmektedir. Yaşama, eziyet görmeme, inanç özgürlüğü, mülk edinme hakkı gibi haklar bu gruba girer. İkinci grubu ise "görev ve liyakat hakkı" denilen haklardan oluşturmaktadır (Konan, 2011).

İnsan hakları, sorunların farkında olmayan, sorunların çözümü için çaba göstermeyenlerden daha çok sorunlar karşısında tepki gösteren, gerçekleri ve inandıklarını ifade edebilen ve toplumsal hayatta etkin rol alan aktif insanların eseridir (Çeçen, 1995). Hak ve özgürlüklerinin farkında olmayan bireyler, bu haklarını istemeyecekleri gibi, ihlal edilmesi durumunda ne yapacağı konusunda bilgi sahibi olmazlar. Ayrıca, yasa ile düzenlenmesi gerektiği halde düzenlenmeyen hak ve özgürlükleri için hukuki mücadele yollarını kullanamazlar (Duman, Karakaya ve Yavuz, 2003).

"Bireyin, kendisini tüm yönlerden geliştirilebilmesi, içinde bulunduğu çevreyi ve toplumu anlayabilmesi, problemleri fark ederek çözümü için zihinsel ve eylemsel olarak harekete geçmesi toplumda etkin ve yararlı bir rol oynayabilmesi ve bu amaçla sorumluluk üstlenebilmesi, ilk olarak sahip olduğu hak ve özgürlüklerin farkında olarak "hak bilinci" edinmesine bağlıdır" (Gülmez, 1998, s. 2-3). Bireylere insan haklarına 
duyarlılık farkındalıkları eğitim yoluyla kazandırılır. Eğitim, insan haklarının korunması ve iyileştirilmesinde en önemli unsurdur. Sevgi, saygı, hoşgörü gibi kavramlar eğitimle kazandırılır. Bu değerlerin edinilmesi insan haklarının iyileştirilmesinde önemli etkendir. Bu nedenle eğitim sisteminin insan haklarına ilişkin önemli bir işlevi bulunmaktadır (Doğan, 2001).

İnsan hakları eğitimi sadece bilişsel süreçleri değil tutum, davranış ve birtakım becerileri de içermektedir. Okul öncesinden başlayıp yükseköğretimin sonuna kadar bu boyutları ile verilemeyen bir insan hakları eğitimi amacına ulaşamayacaktır. Nitekim ülkemizde olduğu gibi dünyada da kişilerin eğitim sistemi içinde uzun bir süre kalmalarına rağmen hem kendi haklarını koruyamamaları hem de başkalarının haklarını ihlal etmeleri verilen insan hakları eğitiminin istenilen düzeyde olmadığını göstermektedir (Karatekin, Merey, Sönmez ve Kuş, 2012). Nitekim bu konuda yapılmış bir araştırmada üniversite öğrencilerinin hak ve özgürlüklere ilişkin farkındalık oluşturulmasında eğitimin önemli bir yeri olduğu belirtilmiştir (Dolmacı ve Kuşat, 2015). Yasaların evrensel değerlere uygun hazırlanması ve uygulanması, aile eğitimleri ve toplumsal duyarlılık faaliyetlerin düzenlenmesinin yanı sıra okul öncesinden yükseköğretime kadar tüm öğretim düzeylerinde insan hakları eğitiminin verilmesi kaçınılmazdır

Yapılan araştırmalarda öğretmenlerin kişisel ve mesleki yeterliliklerinin arttırılması ile öğrencilerin nitelikli ve karakterli biçimde yetişmeleri sağlanabilecektir (Gözütok, 1995; Mentiş Taş, 2004). Millî Eğitim Bakanlığı (MEB) tarafından 2017 yılında yayımlanan "öğretmenlik mesleği genel yeterlilikleri" ilgili belgede öğretmenlerin sahip olması gereken yeterlilikler "mesleki bilgi, mesleki beceri, tutum ve değerler" olmak üzere üçe ayrılmıştır. İnsan hakları yeterliliklerine tutum ve değerler yeterlilik alanında, milli, manevi ve evrensel değerler başlığı altında verilmiştir. İlgili belgede yer verilen insan hakları yeterlilikleri şunlardır: a) Çocuk ve insan haklarını gözetir, b) Bireysel ve kültürel farklılıkları tanır, c) Öğrencilerin milli ve manevi değerlere saygılı, evrensel değerlere açık bireyler olarak yetiştirilmesine katkıda bulunur, d) Doğal çevre ile tarihsel ve kültürel mirasın korunmasında duyarlıdır (MEB, 2017). Özellikle ilk üç madde incelediğinde öğretmenlerin insanı merkeze alarak evrensel değerler çerçevesinde çocukların temel haklarını gözeten, bireysel ve kültürel farklılıkların bilincinde buna uygun davranış içinde olmaları gerektiği vurgulamaktadır. $\mathrm{Bu}$ nedenle öğretmenler, insan haklarıyla ilgili bilgi, beceri ve tutumların öğrencilere kazandırılmasında önemli bir role sahiptir. Eğitim sürecinde hal, hareket ve davranışlarıyla, olaylara bakış açısıyla öğrencilere rol model olacak öğretmen adaylarından insan haklarıyla ilgili bilgi, beceri ve tutuma sahip olmaları ve buna uygun davranış geliştirmeleri beklenmektedir.

Öğretmen adaylarının toplumdaki her birey gibi öncelikle kendine sayg1 duyması, kendisinden farklı düşünenlere, farklı değerlere ve inançlara sahip olanlara saygı göstermesi, toplumsal sorunlara karş1 duyarlılık göstermesi ve problemlerin çözümü için destek olması gerekir. Kendi dışındakilere hayat hakkı tanımayan, başkalarının duygu ve düşüncelerine değer vermeyen, saygı göstermeyenlerin insan hakları anlamında model olmaları beklenemez. Bu nedenle öğretmen adaylarının insan haklarıyla ilgili bilgi, beceri ve tutum sahibi olarak öz farkındalıklarının artırılması önem arz etmektedir (Karaman- Kepenekçi ve Baydık, 2009; Doğan, Torun ve Akgün, 2014; Koran, 2015). Eğitim ortamlarında insan haklarıyla ilgili bilgi, beceri ve tutuma sahip olan bilinçli öğrenciler yetiştirmek için geleceğin öğretmenlerinin bu konuda gerekli kişisel ve mesleki yeterliliğe sahip olması gerekir. Alan yazın tarandığında insan hakları konusu ile ilgili çalışmaların program değerlendirme, ders kitabı inceleme veya insan hakları eğitimine odaklandığı görülmektedir. Bu çalışma ile geleceğin öğretmenleri olacak öğretmen adayları "insan hakları" konusundaki algılarının belirlenmesi amaçlanmaktadır.

\section{YÖNTEM}

$\mathrm{Bu}$ çalışma, nitel araştırma yöntemlerinden olgu bilim desenine göre tasarlanmıştır. Olgu bilim deseni, çeşitli biçimlerde karşımıza çıkabilen, farkında olunan ancak derinlemesine ve ayrıntılı bir anlayışa sahip olunmayan olgulara odaklanır ve bireye tamamıla yabancı olmayan bu olguların detaylı bir şekilde araştırılmasında (Yıldırım ve Şimşek, 2006) kullanılır. 


\section{Araştırma Modeli}

Çalışmada katılımcıların belirlenmesinde amaçlı örnekleme yöntemlerinden kolay ulaşılabilir durum örneklemesi kullanılmıştır (Yıldırım ve Şimşek, 2006). Belirlenen örnekleme yöntemi doğrultusunda Necmettin Erbakan Üniversitesi Ereğli Eğitim Fakültesinde 2. sınıfta öğrenim gören gönüllü öğretmen adaylarına online ortamda (google meet) zihin haritaları eğitimi verilmiştir. Bu eğitime katılan öğretmen adayları arasından gönüllü olanlar çalışma grubunu oluşturmuştur. Tablo 1'de çalışmaya katılan öğretmen adaylarının demografik özellikleri gösterilmiştir.

Tablo 1.

Ögretmen Adaylarının Demografik Özellikleri

\begin{tabular}{|c|c|c|c|c|}
\hline & $\begin{array}{l}\text { Türkçe } \\
\text { Öğretmenliği }\end{array}$ & $\begin{array}{l}\text { Rehberlik ve } \\
\text { Psikolojik } \\
\text { Danışmanlık }\end{array}$ & $\begin{array}{l}\text { İlköğretim Matematik } \\
\text { Öğretmenliği }\end{array}$ & Toplam \\
\hline Kadın & 15 & 7 & 5 & 27 \\
\hline Erkek & 7 & 4 & 4 & 15 \\
\hline Toplam & 22 & 11 & 9 & 42 \\
\hline
\end{tabular}

\section{Veri Toplama Araçları ve Süreçleri}

Çalışmada veri toplama aracı olarak zihin haritası tekniğinden yararlanılmıştır. "Zihin haritası, özellikle hafıza, yaratıcılık, öğrenme ve her türlü beyin işlevine uygun, görsel, bütüncül bir grafik düşünme aracıdır” (Buzan ve Buzan, 2011, s. 31). Zihin haritaları kavramların birbiri ile ilişsisinini daha üst biçimde algılamamıza yardım eder. Coğrafik haritalar dünyanın fiziksel modelini net biçimde görmemizi sağlıyorsa, zihin haritaları da belli bir konu, olgu veya probleme ilişkin, öğrenciler tarafından geliştirilen ilişkilerin zihinsel modellerini görselleştirmektedirler (Saban, 2005). Öğretmen adaylarının insan hakları gibi geniş kapsamlı soyut bir kavramla ilgili algılarının ortaya çıkarılması ve bütüncül olarak görülebilmesi için renk, şekil, simge, kelime ve resimlerle desteklenen zihin haritaları tekniği kullanılmıştır.

Çalışmaya katılan öğretmen adaylarının da yer aldığı üç farklı gruba zihin haritaları eğitimi verilmiştir. Çalışma iki aşamada yapılmıştır. İlk aşamada zihin haritaları konusunda öğretmen adaylarına teorik ve uygulama eğitimi verilmiştir. İkinci aşamada ise ilk çalışmaya katılan ve gönüllü olan katılımcılardan "insan hakları" ile ilgili zihin haritaları oluşturmaları istenmiştir. Çalışmanın her iki aşaması da online olarak "google meet” uygulaması kullanılarak yürütülmüştür.

Çalışmanın güvenirliği için 2 uzman görüşüne başvurulmuştur. Bu süreçte 2 uzman ve araştırmacı temayla ilgili aynı görüşe sahipse görüş birliği olarak kabul edilirken araştırmacı ve uzmanlar farklı görüştelerse bu durum görüş ayrılığı olarak kabul edilmektedir. Çalışmanın güvenilirliği Güvenirlik=Görüş Birliği / (Görüş Birliği + Görüş Ayrılığı) formülü ile en az \%70 seviyesinde güvenilirlik katsayısı ile ortaya konmaktadır (Miles \& Huberman, 1994). Çalışma kapsamında yapılan güvenirlik çalışması için görüşlerine başvurulan uzmanlar arasında \%90 oranında bir uzlaşma (güvenirlik) elde edilmiştir. Şekil 1'de öğretmen adaylarının “insan hakları" ile ilgili zihin haritaları örneklerine yer verilmiştir. 


\section{Şekil 1.}

\section{Insan Hakları ile İlgili Zihin Haritaları Örnekleri}

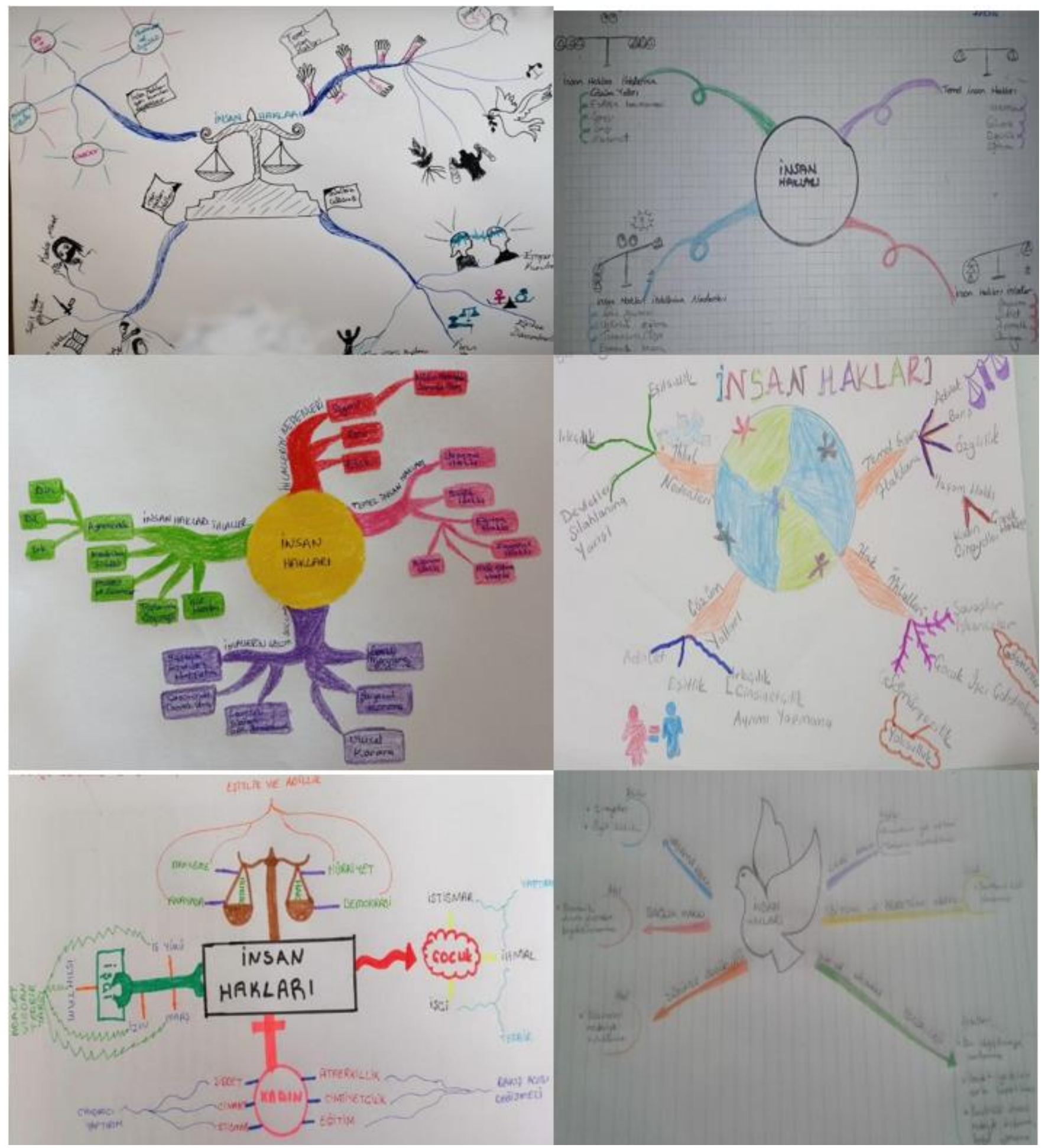

\section{Verilerin Analizi}

Çalışmadan elde edilen verilerin analizinde kullanılan betimsel analiz tekniği ile elde edilen veriler daha önce belirlenen temalara göre mantıklı ve anlaşılır bir biçimde okuyucuya sunulur. Betimlemeler yorumlanır, neden-sonuç ilişkileri incelenerek birtakım sonuçlara ulaşılır (Yıldırım ve Şimşek, 2006, s. 224). Çalışmaya katılan 42 katılımcıdan elde edilen veriler insan hakları/sosyal bilgiler alanında çalışan 2 uzman ve araştırmacı tarafından analiz edilmiştir. Ayrıca hukuksal ifadelerin çözümlenmesinde ve yerleştirilmesinde uzman bir hukukçudan destek alınmıştır. Verilerin analiz edilmesi aşamasında ilk olarak 
katılımcıların "insan hakları” kavramına yönelik çizdikleri zihin haritalarındaki ana dallara göre temalar oluşturulmuş, yan dallardaki resim ve kelimeler dikkate alınarak ise veriler kodlanmıştır. Temaların belirlenmesinde ana dallar, kodların belirlenmesinde ise yan dallar esas alınmıştır. Kodların oluşturulmasında resim ve kelimeler dikkate alınmış ve kodlar ilgili temaların içerisine yerleştirilmiştir. Uzman görüşlerine göre temalar yeniden düzenlenerek son hali verilmiştir. Ayrıca analiz sonuçları frekans, frekans ortalamaları ve yüzde olarak gösterilmiştir.

\section{Etik}

“Öğretmen Adaylarının İnsan Haklarına İlişkin Algıları” ile ilgili çalışmanın hazırlık, veri toplama, analiz ve bilgilerin sunumu olmak üzere tüm aşamalarında bilimsel etik ilke ve kurallara uyulduğu; bu çalışma kapsamında yer verilen bilgiler için kaynak gösterildiğini ve bunlara kaynakçada yer verildiğini; kullanılan verilerde herhangi bir değişiklik yapılmadığını, çalışmanın Committee on Publication Ethics (COPE)' in tüm şartlarını ve koşullarını kabul ederek etik görev ve sorumluluklara riayet edildiğini beyan ederim. Bu çalışmayla ilgili Necmettin Erbakan Ünivrsitesi Sosyal ve Beşeri Bilimler Bilimsel Araştırmalar Etik Kurulu'ndan 2021/123 nolu etik kurul onayı alındı.

\section{BULGULAR}

Çalışmaya katılan öğretmen adaylarının "insan hakları" ile ilgili çizdikleri zihin haritalarının betimsel analizi yapılarak öğretmen adaylarının görüşleri çerçevesinde oluşturulan temalar ve kodlar tablolar şeklinde aşağıda verilmiştir. Tablo 2' de öğretmen adaylarının “insan hakları” ile ilişkilendirdikleri kavramlara yer verilmiştir.

\section{Tablo 2.}

Insan Haklart ile İlişkilendirilen Temel Kavramlar

\begin{tabular}{|c|c|c|c|c|}
\hline Temalar & Temel kavramlar & f & $\%$ & $f_{\text {ort. }}$ \\
\hline \multirow{9}{*}{$\begin{array}{l}\text { Demokrasi } \\
\text { oggeleri }\end{array}$} & Özgürlük & 20 & 47,61 & \multirow{9}{*}{8,33} \\
\hline & Hak/hukuk & 15 & 35,71 & \\
\hline & Adalet & 12 & 28,57 & \\
\hline & Eşitlik & 9 & 21,42 & \\
\hline & Anayasa/kanun/yasa & 6 & 14,28 & \\
\hline & Demokrasi & 6 & 14,28 & \\
\hline & Barış & 4 & 9,52 & \\
\hline & Devlet & 2 & 4,76 & \\
\hline & Onur & 1 & 2,38 & \\
\hline \multirow{7}{*}{ Farklılık } & İnsan & 5 & 11,90 & \multirow{7}{*}{2,71} \\
\hline & Irk & 3 & 7,14 & \\
\hline & Cinsiyet & 3 & 7,14 & \\
\hline & Din & 3 & 7,142 & \\
\hline & İfade & 2 & 4,76 & \\
\hline & Dil & 2 & 4,76 & \\
\hline & Sayg1 & 1 & 2,38 & \\
\hline \multirow{3}{*}{ Sembol } & Terazi & 3 & 7,14 & \multirow{3}{*}{1,66} \\
\hline & Güvercin & 2 & 4,76 & \\
\hline & Zeytin dalı & 1 & 2,38 & \\
\hline
\end{tabular}

Tablo 2'de görüldüğü gibi öğretmen adaylarının “insan hakları” kavramıyla ilişkilendirdikleri kavramların demokrasi ögeleri, farklılık ve sembol boyutlarında yer aldığı görülmektedir. Bu üç boyuttaki kodlara ait frekansların ortalamalarına göre öğretmen adaylarının sırasıyla demokrasi ögeleri (fort.=8,33), farklılık (fort.=2,71) ve sembol (fort.=1,66) boyutlarındaki kodlara yöneldikleri belirlenmiştir. Öğretmen adayları 
“insan hakları" kavramını demokrasi ögeleri boyutunda ilk olarak “özgürlük” (\%47,61) olmak üzere sırasıyla "hak/hukuk" $(\% 35,71)$ ve "adalet" $(\% 28,57)$ kavramlarıyla ilişkilendirirlerken; farklılık boyutunda da öncelikle "insan" $(\% 11,90)$ daha sonra "1rk" $(7,14)$ ve "cinsiyet" $(\% 7,14)$ kavramlariyla ilişkilendirmişlerdir. Öğretmen adayları insan hakları kavramını sembol boyutunda ise ilk olarak "terazi" $(\% 7,14)$ ve daha sonra sirasiyla "güvercin" (\%4,76) ve "zeytin dalı" (\%2, 38) kavramlar1 ile ilişkilendirmişlerdir. Tablo 3'te öğretmen adaylarının "insan hakları” ile ilgili ilişkilendirdikleri anayasal haklara yer verilmiştir.

\section{Tablo 3.}

Insan Hakları ile Illişkilendirilen Anayasal Haklar

\begin{tabular}{|c|c|c|c|c|}
\hline Hak türleri & Anayasal Haklar & $\mathbf{f}$ & $\%$ & $\mathbf{f}_{\text {ort. }}$ \\
\hline \multirow{11}{*}{ Kişi Hakları } & Yaşam hakk1 & 30 & 71,42 & \multirow{11}{*}{6,81} \\
\hline & Din ve vicdan özgürlüğü & 9 & 21,42 & \\
\hline & Düşünce ve ifade özgürlüğü & 8 & 19,04 & \\
\hline & Özel yaşamın gizliliği hakkı & 7 & 16,66 & \\
\hline & Barınma hakkı & 6 & 14,28 & \\
\hline & Dokunulmazlık hakkı & 5 & 11,90 & \\
\hline & Mülk edinme hakkı & 3 & 7,14 & \\
\hline & Seyahat hakk1 & 3 & 7,14 & \\
\hline & Can ve mal güvenliği & 2 & 4,76 & \\
\hline & Haberleşme hakkı & 1 & 2,38 & \\
\hline & Konut dokunulmazlığg hakkı & 1 & 2,38 & \\
\hline \multirow{4}{*}{$\begin{array}{l}\text { Sosyal ve } \\
\text { Ekonomik Hak } \\
\text { ve Ödevler }\end{array}$} & Eğitim hakk1 & 19 & 45,23 & \multirow{4}{*}{5,80} \\
\hline & Çalışma hakkı & 3 & 7,14 & \\
\hline & Sosyal güvenlik hakkı & 1 & 2,38 & \\
\hline & Tüketici hakkı & 1 & 2,38 & \\
\hline \multirow{2}{*}{$\begin{array}{l}\text { Siyasi Haklar } \\
\text { ve Ödevler }\end{array}$} & Dilekçe verme hakkı & 6 & 14,28 & \multirow{2}{*}{2,00} \\
\hline & Seçme ve seçilme hakkı & 6 & 14,28 & \\
\hline
\end{tabular}

Tablo 3'te incelendiğinde öğretmen adaylarının “insan hakları” kavramını kişi hakları (fort.=6,81), sosyal ve ekonomik haklar ve ödevler (fort. $=5,80$ ) ve siyasi hak ve ödevler (fort. $=2.00$ ) boyutları içindeki kodlarla ilişkilendirdikleri görülmektedir. Öğretmen adayları, insan hakları ile kişi haklarının öncelikle "yaşam hakk1" (\%71,42) olmak üzere sirayla "din ve vicdan özgürlüğü” $(\% 21,42)$ ile "düşünce ve ifade özgürlüğü”, $(\% 19,04)$ haklarıyla ilgili olduğunu ifade ettikleri; sosyal ve ekonomik haklar ve ödevlerle ilgili olarak daha çok "eğitim hakkı" (\%45,23), "ekonomik haklar (ihbar tazminatı, kıdem tazminat1, fazla mesai ücreti vb.)" $(\% 11,90)$ ile "çalışma hakkı" $(\% 7,14)$ gibi hakların ilişkili olduğunu ifade etmişlerdir. Öğretmen adaylarının siyasi haklar ve ödevler boyutunda ise insan haklarının "dilekçe verme hakkı" (\%14,28) ve "seçme ve seçilme hakkı" $(\% 14,28)$ gibi haklarla ilişkili olduğunu ifade etmişlerdir. Tablo 4 'te insan hakları ile ilgili ihlallere yer verilmiştir. 
Tablo 4.

Insan Haklart Ihlalleri

\begin{tabular}{|c|c|c|c|c|}
\hline Temalar & İnsan Hakları İhlalleri & $\mathbf{f}$ & $\%$ & fort. \\
\hline \multirow{10}{*}{ İnsanlık dışı } & Kadına şiddet & 11 & 26,19 & \multirow{10}{*}{5,70} \\
\hline & Cinayet & 9 & 21,42 & \\
\hline & İşkence ve kötü muamele & 7 & 16,66 & \\
\hline & Çocuk işçiliği & 5 & 11,90 & \\
\hline & Çocuk istismarı & 4 & 9,52 & \\
\hline & Kadın cinayeti (Ceren Ö., Emine B. vb.) & 4 & 9,52 & \\
\hline & Kadına taciz & 3 & 7,14 & \\
\hline & Yargisız infaz & 2 & 4,76 & \\
\hline & Faili meçhuller & 2 & 4,76 & \\
\hline & Diğer (Açlık, kürtaj, göçmenler...) & 10 & 23,81 & \\
\hline \multirow{6}{*}{ Ayrımcilık } & Din (yasaklama, İslamofobi vb.) & 9 & 21,42 & \multirow{6}{*}{6,50} \\
\hline & Irkçılık & 9 & 21,42 & \\
\hline & Cinsiyet & 8 & 19,04 & \\
\hline & $\begin{array}{l}\text { Çocuk (Aile baskısı, ihmal, çocuk gelin } \\
\text { vb.) }\end{array}$ & 6 & 14,28 & \\
\hline & Eğitim hakkının engellenmesi & 4 & 9,52 & \\
\hline & Dil & 3 & 7,14 & \\
\hline \multirow{6}{*}{ Engelleme } & $\begin{array}{l}\text { Düşünce ve ifade özgürlüğün } \\
\text { engellenmesi }\end{array}$ & 10 & 23,81 & \multirow{6}{*}{5,33} \\
\hline & İşçi haklarının engellenmesi & 8 & 19,04 & \\
\hline & $\begin{array}{l}\text { Toplantı ve gösteri özgürlüğünün } \\
\text { engellenmesi }\end{array}$ & 6 & 14,28 & \\
\hline & Basını engelleme & 3 & 7,14 & \\
\hline & Özel hayatın gizliliği ihlali & 2 & 4,76 & \\
\hline & $\begin{array}{l}\text { Diğer (Uzun tutukluluk süresi, erişim } \\
\text { engeli vb.) }\end{array}$ & 3 & 7,14 & \\
\hline
\end{tabular}

Tablo 4'e göre öğretmen adaylarının zihin haritalarında yer verdikleri insan hakları ihlallerinin insanlık dışı (fort.=5,70), ayrımcılık (fort.=6,50) ve engelleme (fort.=5,33) boyutlarında toplandığı görülmektedir. Öğretmen adaylarına göre insanlık dışı boyutunda "kadına şiddet" $(\% 26,19)$ başta olmak üzere "cinayet" $(\% 21,42)$ ve "işçi haklarının engellenmesi" $(\% 19,04)$ gibi insan hakları ihlallerinin; ayrımcılık boyutunda ise en fazla ihlal edilen insan hakları ihlallerinin "din" (yasaklama, İslamofobi vb.) (\%21,42), "1rkç1l1k" $(\% 21,42)$ ve "cinsiyet" $(\% 19,04)$ ilgili konularda gerçekleşmektedir. Öğretmen adaylarına göre engelleme boyutunda yaşanan insan hakları ihlallerinin sırasıyla "düşünce ve ifade özgürlüğün engellenmesi" $(\% 23,81)$, “toplantı ve gösteri özgürlüğünün engellenmesi” $(\% 14,28)$ ve "basını engelleme “( $\% 7,14)$ şeklinde gerçekleşmektedir. Tablo 5’te insan hakları ihlallerinin nedenlerine yer verilmiştir. 
Tablo 5.

Insan Haklari İhlallerinin Nedenleri

\begin{tabular}{|c|c|c|c|c|}
\hline Temalar & İhlal nedenleri & f & $\%$ & fort. \\
\hline \multirow{6}{*}{$\begin{array}{l}\text { Demokratik } \\
\text { durum }\end{array}$} & Yasaların yetersiz olması & 9 & 21,42 & \multirow{6}{*}{14,76} \\
\hline & $\begin{array}{l}\text { Demokrasi eksikliği (Adaletsizlik, eşitsizlik } \\
\text { vb.) }\end{array}$ & 7 & 16,66 & \\
\hline & Siyasi nedenler & 6 & 14,28 & \\
\hline & Dini nedenler & 4 & 9,52 & \\
\hline & $\begin{array}{l}\text { Geleneksel yap1 (Ataerkillik, kan davaları, } \\
\text { toplum baskıs1) }\end{array}$ & 3 & 7,14 & \\
\hline & Etnik sorunlar & 2 & 4,76 & \\
\hline \multirow{5}{*}{$\begin{array}{l}\text { Birey dışı } \\
\text { durum }\end{array}$} & Göçler (Ekonomik, siyasi, savaş) & 7 & 16,66 & \multirow{5}{*}{13,33} \\
\hline & Savaşlar & 6 & 14,28 & \\
\hline & Terör saldırıları (PKK, DAEŞ vb.) & 6 & 14,28 & \\
\hline & Sömürgecilik & 5 & 11,90 & \\
\hline & $\begin{array}{l}\text { Diğer (İç savaşlar, soykırım, silahlanma } \\
\text { yarışı) }\end{array}$ & 4 & 9,52 & \\
\hline \multirow{3}{*}{$\begin{array}{l}\text { Kişisel } \\
\text { durum }\end{array}$} & Eğitimsizlik & 5 & 11,90 & \multirow{3}{*}{6,54} \\
\hline & Bilinçsizlik & 3 & 7,14 & \\
\hline & Bencillik & 3 & 7,14 & \\
\hline \multirow{3}{*}{$\begin{array}{l}\text { Ekonomik } \\
\text { durum }\end{array}$} & Yoksulluk & 5 & 11,90 & \multirow{3}{*}{7,14} \\
\hline & Ekonomik sıkıntılar & 3 & 7,14 & \\
\hline & Sanayileşme & 1 & 2,38 & \\
\hline
\end{tabular}

Tablo 5'e göre öğretmen adayları zihin haritalarında yer verdikleri insan hakları ihlallerinin nedenleriyle ilgili olarak en çok demokratik durum (fort.= 14,79) boyutundaki kodlar olmak üzere birey dış1 durum (fort.=13,33), kişisel durum (ort. $=6,54$ ) ve ekonomik durum (fort. $=7,14$ boyutlarında yer alan kodlara yöneldikleri görülmektedir. Öğretmen adayları, insan hakları ihlallerine demokratik durum boyutunda başta "yasaların yetersiz olması" (\%21,42) olmak üzere sırasıyla "demokrasi eksikliği (adaletsizlik, eşitsizlik vb.)" (\%16,66) ve "siyasi nedenler" $(\% 14,28)$ gibi nedenlerin yol açtığını düşündükleri görülmektedir. Öğretmen adayları, birey dışı durum boyutunda ise "göçler (ekonomik, siyasi, savaş)" $(16,66)$, "savaşlar" $(14,28)$, "terör saldırıları" (PKK, DAEŞ vb.)" (\%14,28) vb. durumların ihlallere sebep olduğunu düşündükleri görülmektedir. Öğretmen adayları kişisel durum boyutunda insan haklarının "eğitimsizlik" $(\% 11,90)$, "bilinçsizlik" ve $(\% 7,14)$, bencillik $(\% 7,14)$ gibi nedenlerle ihlal edildiğini ifade etmektedirler. Öğretmen adayları ekonomik durum boyutunda ise ihlallere başta "yoksulluk" $(\% 11,90)$ olmak üzere “ekonomik sıkıntılar" $(\% 7,14)$, "sanayileşme" $(\% 2,38)$ gibi nedenlerin yol açtığını belirtmektedirler. Tablo 6'da öğretmen adaylarının insan hakları ihlallerinin çözümüne yönelik önerilerine yer verilmiştir. 
Tablo 6.

İnsan Hakları İhlallerine Yönelik Çözüm Önerileri

\begin{tabular}{|c|c|c|c|c|}
\hline Temalar & Çözüm önerileri & $\mathbf{f}$ & $\%$ & $\mathbf{f}_{\text {ort. }}$ \\
\hline \multirow{8}{*}{$\begin{array}{l}\text { Kamusal } \\
\text { görevler }\end{array}$} & İnsan haklarını koruyucu yasalar & 14 & 33,33 & \multirow{8}{*}{7,62} \\
\hline & Ayrımcılık yapılmaması & 10 & 23,81 & \\
\hline & Kanun ve yasaları uygulama/uyma & 10 & 23,81 & \\
\hline & Eğitim (Çocuk ve aile eğitimi vb.) & 10 & 23,81 & \\
\hline & Halkın bilinçlendirilmesi & 7 & 16,66 & \\
\hline & Caydırıcı cezalar & 5 & 11,90 & \\
\hline & Sosyal düzeni sağlama & 2 & 4,76 & \\
\hline & $\begin{array}{l}\text { Diğer (Tedbir, politika geliştirme, silahlanmayı } \\
\text { önleme) }\end{array}$ & 3 & 7,14 & \\
\hline \multirow{4}{*}{$\begin{array}{l}\text { Bireysel } \\
\text { görevler }\end{array}$} & Bireysel sorumluk üstlenme & 9 & 21,42 & \multirow{4}{*}{4,75} \\
\hline & Sayg1 duyma, & 4 & 9,52 & \\
\hline & Sevgi/merhamet & 4 & 9,52 & \\
\hline & Empati kurma & 2 & 4,76 & \\
\hline \multirow{6}{*}{$\begin{array}{l}\text { Koruyucu } \\
\text { kurumlar }\end{array}$} & $\begin{array}{l}\text { Sivil Toplum Kuruluşları (Uluslararası Af Örgütü, } \\
\text { MAZLUMDER, İHD, TİHV vb.) }\end{array}$ & 11 & 26,19 & \multirow{6}{*}{5,00} \\
\hline & Birleşmiş Milletler & 6 & 14,28 & \\
\hline & Avrupa İnsan Hakları Mahkemesi & 6 & 14,28 & \\
\hline & Amerikan Devletler Örgütü & 3 & 7,14 & \\
\hline & Afrika Birliği Örgütü & 2 & 4,76 & \\
\hline & Avrupa Güvenlik ve İşbirliği Teşkilatı & 2 & 4,76 & \\
\hline \multirow{3}{*}{$\begin{array}{l}\text { Evrensel } \\
\text { sözleşme } \\
\text { ve Belgeler }\end{array}$} & 1989 Çocuk Hakları Sözleşmesi & 3 & 7,14 & \multirow[b]{3}{*}{4,00} \\
\hline & 1948 Birleşmişler Milletler İnsan Hakları Bildirgesi & 3 & 7,14 & \\
\hline & $\begin{array}{l}\text { Diğer (1789 İnsan ve Yurttaş Hakları Bildirgesi, } \\
\text { Kiros Silindiri, Asoka Fermanları, Medine Vesikası } \\
\text { vb.) }\end{array}$ & 6 & 7,28 & \\
\hline
\end{tabular}

Tablo 6' da görüldüğü gibi öğretmen adayları zihin haritalarında yer verdikleri insan hakları ihlallerinin engellenmesine yönelik olarak başta "kamusal görevler" (fort.=7,62) olmak üzere "bireysel görevler" (fort.=4,75), "koruyucu kurumlar" (fort. $=5,00$ ) ve "evrensel sözleşme ve belgeler" (fort. $=4,00$ ) boyutlarında yer alan çeşitli çözüm önerileri sunmuşlardır. Buna göre öğretmen adayları kamusal görevler boyutunda insan hakları ihlallerini önlemeye yönelik ilk olarak "insan haklarını koruyucu yasalar" $(\% 33,33)$ çıkarılmasını daha sonra "ayrımcılık yapılmaması" (\%23,81), "kanun ve yasaları uygulama/uyma" $(\% 23,81)$, "eğitim (çocuk ve aile eğitimi vb.)" (\%23,81), "halkın bilinçlendirilmesi” $(\% 16,66)$ vb. çözüm önerileri sundukları görülürken; bireysel görevler boyutunda ise başta "bireysel sorumluk üstlenme" $(21,42)$ olmak üzere "saygı duyma”, $(9,52)$, "sevgi/merhamet” $(9,52)$, “empati kurma” $(\% 4,76)$ vb. çözüm önerileri getirdikleri görülmektedir. Diğer taraftan öğretmen adayları "koruyucu kurumlar" boyutunda insan haklarını engellemeye ve çözmeye yönelik başta "Sivil Toplum Kuruluşları (Uluslararası Af Örgütü, MAZLUMDER, İHD, TİHV vb.)" (\%26,19) olmak üzere Birleşmiş Milletler $(\% 14,28)$ ve "Avrupa İnsan Hakları Mahkemesi” (\%14,28) gibi sivil, resmi, ulus ve uluslararası kurumların olduğunu belirtmektedirler. Ayrıca, öğretmen adayları insan hakları ihlallerinin engellenmesi için "evrensel sözleşme ve belgeler" boyutunda tarihten günümüze "1989 Çocuk Hakları Sözleşmesi” (\%7,14), "1948 Birleşmişler Milletler İnsan Hakları Bildirgesi” $(\% 7,14)$ ile "diğer" boyutunda "1789 İnsan ve Yurttaş Hakları Bildirgesi”, "Kiros Silindiri”, Asoka Fermanları, "Medine Vesikası” (\%14,28) gibi belge ve sözleşmelerin yer aldığını ifade etmektedirler. 


\section{TARTIŞMA / SONUÇ / ÖNERI}

Öğretmen adayları insan hakları kavramıyla ilgili görüşlerinin analizinde şu sonuçlara ulaşılmıştır. Öğretmen adaylarının insan hakları kavramına yönelik olarak görüşleri temel kavramlar, anayasal haklar, ihlaller, nedenler ve çözüm önerileri olmak üzere 5 temada toplanmaktadır.

Öğretmen adayları insan haklarıyla demokrasi ögeleri kapsamında özgürlük, hak/hukuk, adalet, eşitlik, anayasa/kanun/yasa, demokrasi, barış, devlet ve onur gibi kavramları ilişkilendirmişlerdir. Bu kavramların aynı zamanda demokrasi ile doğrudan ilgili kavramlar olduğu da görülmektedir. Dolayısıyla demokrasi ve insan haklarının birbiri ile yakından ilişkili olduğu konusunda farkındalık sahibi olduklarını göstermektedir. Diğer taraftan öğretmen adaylarının farklılık boyutunda 1rk, cinsiyet, din, ifade, dil ve saygı gibi ifadelerle insan haklarını ilişkilendirmeleri onların bu kavramların insan hakları bağlamında öneminin bilincinde oldukları söylenebilir. Öğretmen adaylarının zihin haritalarındaki resimlerle adalet ve eşitlik için teraziyi, toplumsal barış için güvercin ve zeytin dalını ilişkilendirmeleri onların adalet, eşitlik, barış, huzurun sağlanması konusunda bu ifadelerin sembolik değere sahip olduklarını düşündükleri söylenebilir.

İnsan haklarıyla ilgili olarak uluslararası alanda üç temel insan hakları kuşağı ön plana çıkmaktadır. Bunlar; birinci kuşak, ikinci kuşak ve üçüncü kuşak haklar olarak sınıflandırılmaktadır. Kişi özgürlükleri ve siyasal hakları içeren birinci kuşak haklarında temel olarak "yaşama hakkı" konusu ön plana çıkmaktadır (Yeşilçayır, 2020). Öğretmen adaylarının çoğunluğu insan haklarıyla, kişi hakları kapsamında ve anayasal bütün hakların üzerinde yer alan "birincil hak" olan yaşam hakkının ilişkili olduğunu düşünmektedirler. Yaşam hakkının ardından din ve vicdan özgürlüğü ile düşünce ve ifade özgürlüğü gibi anayasal kişi haklarının insan haklarıyla ilgili olduğunu düşündükleri belirlenmiştir. Buna göre öğretmen adaylarının fiziksel var oluşu ifade eden yaşam hakkıyla birlikte istediği inanca sahip olma ve inancını yaşama, düşünme ve düşündüğünü ifade etme özgürlüğünün de önemli olduğunu düşündükleri söylenebilir.

Zihin haritalarında öğretmen adayları ikincil kuşaklar olarak tanımlanan sosyal ve ekonomik haklar ve ödevler içerisinde yer alan eğitim alma hakkı yanında ekonomik haklar (ihbar tazminatı, kıdem tazminatı, fazla mesai ücreti vb.), çalışma hakkı, sosyal güvenlik hakkı, tüketici hakkı gibi anayasal hakları insan haklarıyla ilişkilendirmeleri bu hakların farkında oldukları şeklinde söylenebilir. Diğer taraftan öğretmen adayları siyasi haklar ve ödevler kapsamında dilekçe verme hakkı ile seçme ve seçilme hakkının temel insan haklarıyla ilgili olduğunu ifade etmektedirler.

Öğretmen adaylarının zihin haritalarında insanlık dışı boyutunda yer verdikleri kadına şiddet, cinayet, işkence ve kötü muamele, çocuk işçiliği, çocuk istismar, kadın cinayeti (Ceren Ö., Emine B. vb.), kadına taciz, yargısız infaz, faili meçhuller, açlık, kürtaj, göçmenler vb. durumların insan hayatına dolaylı veya doğrudan olumsuz etkisi olan insan hakları ihlalleri olduğu belirtilmektedir. Elbette, şiddet, işkence ve kötü muamele, cinayet gibi insanlık dışı eylemler kadınlar kadar erkekleri de olumsuz etkilemektedir. Ancak yüzde olarak bir karşılaştırma yapıldığında çoğunlukla kadın ve çocukların istismara uğradıkları gerçeği ortaya çıkmaktadır (Varl1, 2020).

İnsan hakları; 1rk, cinsiyet, milliyet, etnik köken, dil, din veya başka herhangi bir statüden bağımsız olarak tüm insanların doğasında var olan haklardır (UN, 2019: Akt. Varlı, 2020). Zihin haritalarındaki yer alan görüşlerine göre öğretmen adayları, din (yasaklama, İslamofobi vb.), dil, ırkçılık, cinsiyet, çocuk (aile baskısı, ihmal, çocuk gelin vb.) ve eğitim hakkının engellenmesi gibi konularda ayrımcılık yapılarak insan hakları ihlallerinin gerçekleştiğini ifade etmeleri ihlallerinin bilincinde olduklarını göstermektedir. Farklı kültürlerde insan haklarının uygulanması ve geliştirilmesi sırasında birtakım zorluklarla karşılaşılmaktadır. Bunun nedeni, insan haklarının dünyanın her yerinde evrensel olarak kabul edilmemesidir. Örneğin, kadın haklarını desteklemek için hizmet vermek bazı ataerkil kültürlerde çatışmaya neden olabilir (Varlı, 2020). İnsan hakları ihlallerine yol açan kültürel unsurların elimine edilmesinde ulusal ve uluslararası kurum ve kuruluşların çabalarının yanında kültürel değişimin zorluk içermesinden dolayı okul öncesinden başlayarak eğitim yoluyla değişimin sağlanması daha kesin netice verebilecektir. 
Öğretmen adaylarına göre düşünce ve ifade özgürlüğünün engellenmesi, işçi haklarının engellenmesi, toplantı ve gösteri özgürlüğünün engellenmesi, basını engelleme, özel hayatın gizliliği ihlali, uzun tutukluluk süresi, sosyal medyaya erişim engeli gibi hak ihlallerinin meydana gelmektedir. İnsan hakları; yaşam, düşünce ve ifade özgürlüğünü; çalışma, eğitim, sağlık hakkını ve daha fazlasını içermektedir. Tüm insanlar bu haklara sahiptir (UN, 2019: Akt. Varl1, 2020). İnsan haklarının öneminin farkına varılabilmesi için bireysel veya toplum olarak özellikle kamu görevlilerinin bir eğitim sürecinden geçmeleri gereklidir (Çotuksöken, 2010).

Öğretmen adayları, insan hakları ihlallerinin yasaların yetersiz olması, demokrasi eksikliği (adaletsizlik, eşitsizlik vb.), siyasi, dini, geleneksel yapı (ataerkillik, kan davaları, toplum baskısı), etnik sorunlar gibi nedenlerden kaynaklandığını ifade etmişlerdir. Öğretmen adaylarının belirttiği insan hakları ihlallerinin nedenlerinin demokrasi kültürünün eksikliğinden meydana geldiği söylenebilir. Bu durumda insan haklarının ayrılmaz bir parçası (Hürfikir, 2004) olan demokrasi kültürünün güçlendirilmesinin gerekli olduğu görülmektedir.

Öğretmen adayları, insan hakları ihlallerinin göçler (ekonomik, siyasi, savaş), savaşlar, terör saldırıları (PKK, DAEŞ vb.), sömürgecilik, iç savaşlar, soykırım, silahlanma yarışı gibi birey dışı nedenlerden kaynaklandığını ifade etmişlerdir. Suriye, Afganistan, Yemen, Libya vb. birçok ülkedeki iç savaşta hayatını kaybeden, sakat kalan ve göçe zorlananlar, PKK, DAEŞ benzeri illegal örgütlerin kaçırdığı, infaz ettiği sivil veya askerler, tarihten günümüze özellikle kolonyalist ülkelerin sömürgelerde öldürdüğü ve mağdur ettiği, köleleştirdiği, Srebrenitsa'da, Hocalı'da, Doğu Türkistan'da, Nazi Almanya'sında katliama uğrayanlar yakın tarihten günümüze insan hakları ihlallerini en acı biçimde yaşayanlardır. Öğretmen adayları bu ağır insan hakları ihlallerinin ve nedenlerinin farkında olduklarını zihin haritalarında resim ve sözcüklerle vurgulamışlardır.

Öğretmen adayları engellilere yönelik insan hakları ihlallerine zihin haritalarında yer vermemişlerdir. Buna ülkemizde engellilere yönelik yasal düzenlemeler, yerel idarelerin engellilere yönelik faaliyetlerinin yeterli olduğunu düşünmelerinden ileri gelmiş olabilir. Ancak hem ulusal düzeyde hem de uluslararası düzeyde engellilere yönelik birçok yasal düzenleme yapılmasına karşın engellilere yönelik ayrımcılık yapılmaktadır (Öztürk, 2011; Altuntaş ve Doğanay, 2017). Yine yaşlılara yönelik yapılan ihlallerin zihin haritalarında yer almadığ belirlenmiştir. Buna öğrencilerin geleneksel aile çevrelerinden gelmelerinin etkisi olabilir. Bununla birlikte yaşlıların, hırsızlık, gasp, yetersiz beslenme, ihmal, şiddet hatta cinayetle karşı karşıya kaldıkları da bir gerçektir.

Temel hakların ve sorumluluklarının ne olduğunun tam olarak bilinmeyişi, hakların kullanımına ve korunmasına ilişkin farkındalık düzeyinin yeterince olmaması toplumsal saygı ve hoşgörünün azalmasına ve demokrasi, özgürlük ve eşitliğin ivme kaybetmesine yol açar (Dolmacı ve Kuşat, 2015). Zihin haritalarına göre öğretmen adayları, eğitimsizlik, bilinçsizlik ve bencillik gibi kişisel durumların da insan hakları ihlallerine neden olduğunu; bireysel sorumluk üstlenme, başkalarına saygı duyma, sevgi/merhamet gösterme, empati kurma gibi bireysel görevler üstlenerek bu tür ihlallerin engelleneceğini ve sorunların giderilmesine katkı sunacağını düşünmektedirler. Nitekim, 1739 sayılı Milli Eğitim Kanunu'nda da belirtildiği gibi insan hakları ve demokrasinin temel niteliklerine sahip yurttaşların yetiştirilmesi ancak okullardaki eğitimle gerçekleştirilebilecektir (Gülmez, 2001). Ayrıca, öğretmen adaylarına göre yoksulluk, ekonomik sıkıntılar, sanayileşme gibi ekonomik durumların da insan hakları ihlallerine neden olmaktadır.

Öğretmen adayları insan hakları ihlallerini engellemek ve çözmek için insan haklarını koruyucu yasalar, ayrımcılık yapılmaması, kanun ve yasaları uygulama/uyma, eğitim (çocuk ve aile eğitimi vb.), halkın bilinçlendirilmesi, caydırıcı cezalar, sosyal düzeni sağlama, tedbir, politika geliştirme, silahlanmayı önleme gibi çözüm yollarının olduğu görüşündedirler. Bu nedenle günümüzde yaşanan toplumsal ve bireysel sorunların çözümü için insan haklarına saygılı, demokratik yurttaşlar yetiştirmek büyük önem arz etmektedir (Ulusoy ve Erkuş, 2016). Başka bir ifade ile ancak eğitilen ve öğrenim gören, bilgi sahibi insan tüm hakların 
korunmasına dikkat eder. Kendisinin ve başkalarının hakları konusundaki taleplere karşı duyarlı olur (Çotuksöken, 2010, s. 35).

Öğretmen adayları insan haklarını ihlallerini engellemek ve çözmek için Sivil Toplum Kuruluşları (Uluslararası Af Örgütü, MAZLUMDER, İHD, TİHV vb.), Birleşmiş Milletler, Avrupa İnsan Hakları Mahkemesi, Amerikan Devletleri Örgütü, Afrika Birliği Örgütü, Avrupa Güvenlik ve İşbirliği Teşkilatı gibi resmi veya sivil koruyucu kurumlara ihtiyaç duyulduğunu düşünmektedirler. Ayrıca öğretmen adayları tarihten günümüze insan hakları ihlallerini engellemeye yönelik olarak Çocuk Hakları Sözleşmesi, Birleşmişler Milletler İnsan Hakları Bildirgesi, İnsan ve Yurttaş Hakları Bildirgesi, Kiros Silindiri, Asoka Fermanları, Medine vesikası gibi sözleşme ve belgelerin düzenlendiği bilgisine sahip oldukları görülmektedir. Uğrunda çok uzun, zor ve yoğun mücadele verilen insan hakları mücadelesinin tarihi sürecini yansıtan kurum, sözleşme ve belgelerle ilgili (Kara, 2017) öğretmen adaylarının bilgi sahibi oldukları söylenebilir.

\section{KAYNAKÇA}

Altuntaş N. \& Doğanay G. (2017). Toplumsal Dışlanma Pratikleri Üzerinden Trabzon'da Engelli Kadınlar. Sosyoloji Araştırmaları Dergisi, 20(2) 1-48.

Buzan, T. \& Buzan, B. (2011). Zihin haritaları. (Çev. Güntülü Tercanlı). İstanbul: Alfa Yayınları.

Çeçen, A. (1995). İnsan hakları. Ankara: Gündoğan Yayınları.

Çotuksöken, B. (2010). İnsan hakları ve felsefe. İstanbul: Papatya Yayınları.

Doğan, İ. (2001). Vatandaşlık, demokrasi ve insan hakları. Ankara: PegemA Yayıncılık.

Doğan, Y., Torun, F. \& Akgün, H. İ. (2014). Okul öncesi öğretmen adaylarının çocuk haklarına ilişkin tutumlarının çeşitli değişkenlere göre incelenmesi. International Journal of Human Sciences. 11 (2).

Dolmacı, N. \& Kuşat, N. (2015). Üniversite gençliğinin vatandaşlık hak ve sorumluluklarına ilişkin bilinç ve farkındalıkları üzerine bir araştırma: Isparta Meslek Yüksekokulu Örneği. Muhasebe ve Finansman Dergisi, (65), 161-180. Doi: 10.25095/mufad.396523.

Duman, T., Karakaya, N. \& Yavuz, N. (2003). Vatandaşlık bilgisi. Ankara: Gündüz Eğitim ve Yayıncılık.

Gözütok, F. D. (1995). Öğretmenlerin demokratik tutumları. Ankara: Ekin.

Gülmez, M. (1998). Belgelerle insan hakları eğitimi Birleşmiş Milletler onyılı. Ankara: TODAİ Yayınları

Gülmez, M. (2001). İnsan hakları ve demokrasi eğitimi. Ankara: TODAİ Yayınları.

Hürfikir, Y. (2004). İlköğretim 2. kademe sosyal bilgiler derslerinin demokrasi eğitimindeki yeri: öğretmen görüşleri. (Yayımlanmamış Yüksek Lisans Tezi). Karadeniz Teknik Üniversitesi, Sosyal Bilimler Enstitüsü, Trabzon.

Kadın Cinayetlerini Durduracağız Platformu, (2020). Nisan 2020 başvuru karşılama raporu. www.Kadincinayetlerinidurduracagiz.Net/Aciklamalar/2912/Nisan-2020-Basvuru-Karsilama-Raporu, adresinden 10.02.2021 tarihinde erişilmiştir.

Kara, C. (2017). İnsan hakları. R. Turan (Ed.). İnsan hakları ve demokrasi içinde. Ankara: PegemA Yayincilik.

Karaman-Kepenekci, Y. \& Baydık, B. (2009). Zihin engelliler öğretmen adaylarının çocuk haklarına ilişkin tutumlar1. Ankara Üniversitesi Eğitim Bilimleri Fakültesi Dergisi, 42(1): 329-350.

Karatekin, K., Merey, Z., Sönmez, Ö. Faruk \& Kuş, Z. (2012). Sosyal bilgiler öğretmen adaylarının insan hakları eğitimine yönelik tutumları. Turkish Studies-International Periodical For The Languages, Literature And History Of Turkish Or Turkic. 7/4, 2193-2207.

Kartal, A., Öksüz, Y., Baba Öztürk, M. \& Güven Demir, E. (2018). Sınıf öğretmeni adaylarının demokrasi algısı: Polonya-Türkiye karşılaştırması. İlköğretim Online 17(2), 562-579. Doi 10.17051/İkonline.2018.418903

Konan, B. (2011). İnsan hakları ve temel özgürlükler açısından Osmanlı Devleti’ne bakış. Gazi Üniversitesi Hukuk Fakültesi Dergisi, 15(4), 253-288.

Koran, N. (2015). Öğretmenlere yönelik çocuk hakları ve hak ihlalleri eğitiminin değerlendirilmesi üzerine nitel bir çalışma. 3rd National Congress of Child Development and Education, Hacettepe University Faculty of Health Sciences Journal, (Congress Book). 
Mentiş Taş, A. (2004). Sosyal bilgiler öğretmenliği eğitimi program standartlarının belirlenmesi. Eğitim Bilimleri Fakültesi Dergisi, 37(1), 28-51.

Miles, M. B \& Huberman, A. M. (1994). Qualitative data analysis. Thousand Oaks, Ca: Sage.

Millî Eğitim Bakanlığı [MEB] (2017). Öğretmenlik mesleği genel yeterlilikleri. Ankara: Öğretmen Yetiştirme ve Geliştirme Genel Müdürlügüü. https://oygm.meb.gov.tr/meb_iys_dosyalar/2017_12/11115355_yyretmenlyk_mesleyy_genel_yeterly klery.pdf adresinden 01.01.2021 tarihinde erişilmiştir.

Öztürk, M. (2011). Türkiye'de engelli gerçeği. İstanbul: MÜSİAD Cep Kitapları: 30.

Saban, A. (2005). Çoklu zekâ teorisi ve eğitim. Ankara: Nobel Yayın Dağıtım.

The UN Refugee Agency [UNHCR], (2020a). Bölgesel mülteci ve dayanıkl1lık planı, 2019-2020. https://www.unhcr.org/tr/wp-content/uploads/sites/14/2020/11/UNHCR-Turkey-Operational-UpdateOctober-2020.pdf adresinden 10.01.2021 tarihinde erişilmiştir.

The UN Refugee Agency [UNHCR], (2021b). Güncel faaliyetler. https://www.unhcr.org/tr/wpcontent/uploads/sites/14/2021/03/UNHCR-Turkey-Operational-Update-January-2021-TRKf.pdf adresinden 10.01.2021 tarihinde erişilmiştir.

Ulusoy, K. \& Erkuş, B. (2016). İlkokul 4. sınıfta insan hakları, yurttaşlık ve demokrasi dersinin okutulmasına ilişkin sınıf ve sosyal bilgiler öğretmenlerinin görüşlerinin incelenmesi. Adıyaman Üniversitesi Sosyal Bilimler Enstitüsü Dergisi, 8(24), 1143-1172.

Uygun, O. (2000). İnsan Hakları Kuramı. K. Tankuter (Ed.). İnsan hakları içinde. İstanbul: Cogito Yap1 Kredi Yayınları.

Varlı, N. (2016). Kültürlerin insan hakları ihlallerine etkileri ve çözüm önerisi. İnsan ve Sosyal Bilimler Dergisi, 3(2), 622-638.

Yeşilçayır, C. (2020). İnsan haklarında kuşaklar tartışması ve bir çözüm denemesi. Temaşa Felsefe Dergisi, (13), 73-85.

Yıldırım, A. \& Şimşek, H. (2006). Nitel araştırma yöntemleri. Ankara: Seçkin Yayıncılık.

\section{EXTENDED ABSTRACT}

Simultaneous with the existence of humanity in the world, human rights, after the Second World War, have become a widespread a concept and a universal issue. At national and international levels, serious human rights violations have been taking place around the world despite many measures and regulations. There may be various definitions of human rights. However, if it is defined on the basis of its most striking quality, human rights can be defined as the rights of all people, without any discrimination, simply because they are human (Uygun, 2000).

With this study, it has been aimed to determine the perceptions of teacher candidates, about human rights. 42 teacher candidates studying at Necmettin Erbakan University, Ereğli Faculty of Education in departments of Turkish Language Teaching, Guidance and Counseling, and Mathematics Teaching participated in this study. The phenomenology design, one of the qualitative research methods has been adopted in the study, and the data have been collected through mind maps technique. In the analysis of the data describe analysis technique has been used. During data analysis, firstly, themes have been created according to the main branches in the mind maps of the participants regarding "human rights", and the data have been coded by taking the pictures and words in the sub-branches into consideration.

Opinions of teacher candidates about human rights have been categorized under five themes: Basic concepts related to human rights, constitutional rights, violations, causes and solutions. It can be concluded that the teacher candidates have knowledge about the basic concepts of human rights, violations, causes of violations and their solutions.

Within the scope of human rights and elements of democracy, the teacher candidates related concepts such as freedom, law, justice, equality, constitution law, democracy, peace, state and honor with human rights. It has also come out that these concepts are directly related to democracy. In their mind maps, teacher candidates associated scales for human rights, justice and equality, dove nad olive branch for social peace. Accordingly, it can be said that teacher candidates think that these concepts have symbolic value in terms of justice, equality, serenity and peace. 
In the mind maps of the teacher candidates, violence against women, murder, torture and ill-treatment child labor, child abuse, harassment, extrajudicial execution, unsolved murders, hunger, abortion, immigrants, etc. are human rights violations that have a direct or indirect negative impact on human life. Inhumane acts such as violence, torture, ill-treatment and murder affect men as well as women. However, a comparison as a percentage reveals the fact that mostly women and children are abused (Varl1, 2020).

The teacher candidates by expressing discrimination in matters such as religion (prohibition, Islamophobia, etc.), racism, gender, children (family oppression, neglect, child bride, etc.), obstruction of the right to education and language have shown that they are of the violations of human rights. Moreover, they think that violations of rights such as obstructing freedom of thought and expression, blocking workers' rights, blocking freedom of assembly and demonstration, blocking the press, violation of privacy of private life, prolonged detention period, and access to social media occur.

The teacher candidates have stated that human rights violations are caused by inadequate laws, lack of democracy (injustice, inequality, etc.), political, religious, traditional structure (patriarchy, blood feuds, social pressure), and ethnic problems. It can be said that the human rights violations stated by the teachers are caused due to the lack of democracy culture. Additionally, teacher candidates have stated that human rights violations are caused by nonindividual situations such as migration (economic, political, war), wars, terrorist attacks (PKK, Daesh, etc.), colonialism, genocide, and arms race.

According to their mind maps, teacher canditates think that violations such as lack of education, unconsciousness and selfishness can be prevented by undertaking individual tasks such as assuming individual responsibility, respecting others, showing love / compassion, and empathy. The teacher candidates think that in order to prevent human rights violations, it is necessary to use solutions such as the enacting laws protecting human rights, nondiscrimination, law enforcement / obeying the laws, education (child and family education, etc.), public awareness, deterrent penalties, maintaining social order, measures, policy development, and prevention of armament.

Legal reforms can be made to eliminate inadequacy of the laws, which are considered to be among the reasons for violations, to protect human rights and to prevent violations, and deterrent penalties can be imposed. Legal arrangements should be made especially to protect women and children.

Furthermore, although issues that require the change of the social and cultural structure such as family pressure, blood feuds, patriarchy, which are among the reasons for the violations, are difficult in addition to deterrent penalties, human rights violations can be reduced, or even can be stopped, through activities aimed at raising awareness about human rights. 